
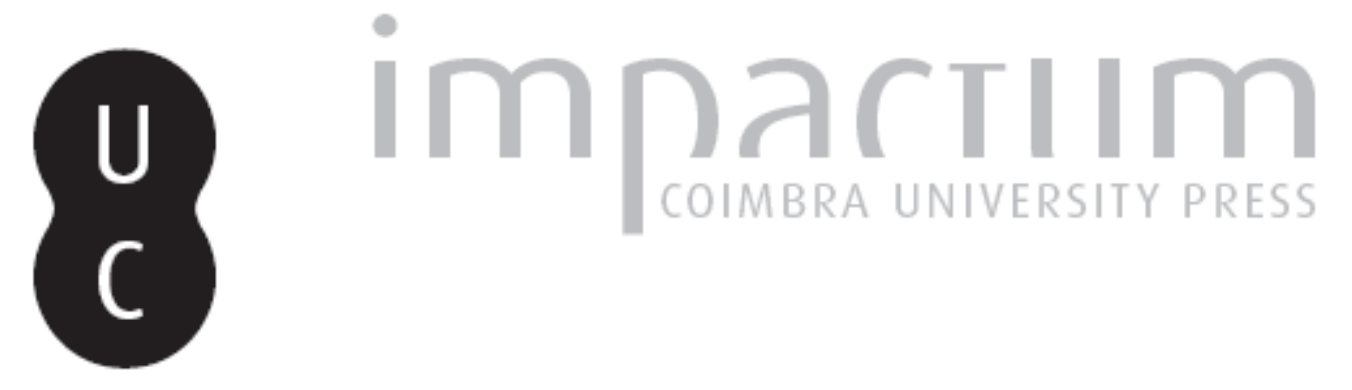

\title{
A diversidade dos riscos ditos ecológicos
}

Autor(es): Rebelo, Fernando

Publicado por: Associação Portuguesa de Riscos, Prevenção e Segurança

URL persistente:

URI:http://hdl.handle.net/10316.2/40061

DOI:

DOI:https://doi.org/10.14195/1647-7723_11_8

Accessed : $\quad$ 26-Apr-2023 14:34:21

A navegação consulta e descarregamento dos títulos inseridos nas Bibliotecas Digitais UC Digitalis, UC Pombalina e UC Impactum, pressupõem a aceitação plena e sem reservas dos Termos e Condições de Uso destas Bibliotecas Digitais, disponíveis em https://digitalis.uc.pt/pt-pt/termos.

Conforme exposto nos referidos Termos e Condições de Uso, o descarregamento de títulos de acesso restrito requer uma licença válida de autorização devendo o utilizador aceder ao(s) documento(s) a partir de um endereço de IP da instituição detentora da supramencionada licença.

Ao utilizador é apenas permitido o descarregamento para uso pessoal, pelo que o emprego do(s) título(s) descarregado(s) para outro fim, designadamente comercial, carece de autorização do respetivo autor ou editor da obra.

Na medida em que todas as obras da UC Digitalis se encontram protegidas pelo Código do Direito de Autor e Direitos Conexos e demais legislação aplicável, toda a cópia, parcial ou total, deste documento, nos casos em que é legalmente admitida, deverá conter ou fazer-se acompanhar por este aviso. 
questiona-se sobre se a investigação pode enriquecer a acção sobre o terreno. A Geografia está presente na maior parte das comunicações, no entanto, e curiosamente, nenhum dos seus autores se apresenta como geógrafo...

O livro termina com cinco anexos (p. 303-314) e um longo índice de matérias (315-325). No seu conjunto, Crues du Gard 2002: retour d'expérience é uma obra muito importante para os responsáveis políticos, para os funcionários superiores das autarquias e para os investigadores da temática dos riscos que trabalham nas regiões atingidas, mas o modo como todas as componentes deste complexo problema foram abordadas permite tirar lições para outras regiões mediterrâneas nas quais o nosso país também se integra.

\section{Referência bibliográfica}

REBELO, Fernando (1995) - «Hommes et érosion dans le centre et lenord du Portugal. Lecas du bassindu Mondego». Territorium, 2, p. 5-10.

\section{A diversidade dos riscos ditos ecológicos}

\section{Fernando Rebelo}

Da autoria de Loic Chauveau, jornalista, colaborador de importantes revistas relacionadas com o ambiente, o Petit atlas des risques écologiques (Paris, Petite Encyclopédie Larousse, 2004, 128 p.) aflora, com um texto simples e muita ilustração de grande qualidade, uma enorme diversidade de riscos relacionados com o ambiente.

Depois de um curto prefácio, seguem-se seis capítulos pelos quais se distribuem os diferentes riscos ditos ecológicos. "L'atmosphère empoisonnée" é o primeiro capítulo e trata, entre outros temas, do efeito de estufa, das ameaças à camada de ozono e da poluição das cidades. O segundo, "L'or bleu en danger" dedica-se à água doce enquanto o terceiro, "Péril sur les océans", se debruça sobre a água dos mares e tudo o que com ela se relaciona como, por exemplo, o litoral, os corais ou a pesca em exagero. Continuando com títulos sugestivos, o quarto capítulo intitula-se "Un sol nourricier surexploité"; aí se trata da desertificação e da deflorestação, mas também da poluição química dos solos e da biodiversidade. "L'homme malade du progrès", o quinto capítulo, dedica-se a problemas demográficos, de degradação do meio urbano, de lixos, de alimentação e saúde, de doenças, de consequências das guerras, etc. O último capítulo, "La société écologique" fala da ecologia, mas preocupa-se com a protecção do ambiente, com a gestão da água, com a reciclagem dos lixos e com as energias renováveis.

Dir-se-á que o livrinho é superficial, que não aprofunda os temas. Claro, ele é apenas uma pequena enciclopédia. No entanto, está cheio de informações e números, como de fotografias e mapas, não deixando de mostrar alguns esquemas muito didácticos. Em suma, o jornalismo científico tem o seu lugar na sociedade, podendo revelar-se fundamental na consciencialização do público leitor. 